\title{
Technical Embroidery for Smart Textiles: Review
}

\author{
Viktorija Mecnika ${ }^{1}$, Melanie Hoerr ${ }^{2}$, Ivars Krievins ${ }^{3}$, Stefan Jockenhoevel ${ }^{4}$, Thomas Gries ${ }^{5}$, \\ 1,2, 4, 5 Institut fuer Textiltechnik of RWTH Aachen, \\ ${ }^{1,3}$ Institute of Design Technologies, Riga Technical University
}

\begin{abstract}
Traditionally embroidery is known as a conventional technique of textile decoration. Since the niche of technical textiles is rapidly expanding and is the main field of innovation and research in textile and apparel industry, embroidery is found in a variety of new functional applications due to the unique opportunity of creating three-dimensional light-weight structures and laying threads on the base material in all directions. As the field of smart textiles is vast per se and is associated with technical textiles and wearable technologies, the main applications of the embroidery may be described accordingly as ones for technical applications. In the sphere of medical textiles, embroidery is a relatively new technique, but is successfully used for wounddressing development and innovative solutions for tissue engineering due to the opportunity of creating three-dimensional structures from fine polymer materials. Another advantageous characteristic of goods developed by embroidery is dimensional stability of manufactured textile structures. Due to these particularities embroidery is used widely also for such technical applications as development of heating grids, shielding, conductive interconnections, intelligent textile sensors and interfaces etc. Moreover, a large variety of materials and threads can be used in prototyping by the technique, e.g., conductive threads, metal wires, laminated polymer and carbon fibers.

One of the challenging sub-sectors of intelligent textiles and smart textiles for healthcare applications is the research and development of textile sensors for biometrics and measurement of physical parameters. Most of the mentioned biosensors are implemented by transferring the principles of conventional actuators to the textile structures.
\end{abstract}

Keywords - Conductive yarns, embroidered sensors, e-textiles, medical textiles, smart textiles.

\section{INTRODUCTION}

Smart and intelligent textiles are a field of the multidisciplinary research arousing interest in many industry sectors due to promising outlooks in a great variety of applications. One of the technological approaches often addressed to ensure manufacturing of such products is embroidery, which is traditionally known as a conventional technique for decorative treatment of textiles. Embroidery handworks are found almost in every world culture and its origins go down to the ancient civilizations. Within the industrial revolution, embroidery came on the mass production and its technical scopes have been significantly extending along with technological progress (1). Till now embroidery has been one of the most used textile decorative surface treatment techniques and is an inseparable part of design in high-street, prêt-à-porte and haute couture fashion throughout decades.

At present, embroidery is found in a variety of functional applications and is widely used in manufacturing of technical textiles. In this sphere, one of the most demanded processing techniques based on embroidery technology is Tailored Fiber Placement (TFP). This method ensures orientation of a fiber or cord on the ground material in all directions, creation of threedimensional structures and offers vast opportunities in structure and shape design (2) (Fig. 1). According to the specific technical requirements of the development and technical specifications of the embroidery machine, a great variety of materials can be used as a cord and ground fabric, e.g., conductive threads, metal wires, laminated polymer and carbon fibers.

TFP technique is used in reinforcement structure development, manufacturing of heating grids, shielding, conductive interconnections, textile sensors and interfaces etc. Moreover, embroidery technique ensures continuous two (2D) and three-dimensional (3D) fiber arrangement. Twodimensional embroidery provides the development of a textile compound across $X$ and $Y$ axes over a plain. Three-dimensional embroidery can be implemented by creating a multi-layer textile structure across $X, Y$ and $Z$ axes. Another approach to obtain a 3D structure is the unfolding of specifically manufactured 2D structure.

One more processing technique transferred to technical applications is chemical embroidery which is originally used for machine-made lace manufacturing. The pattern is usually embroidered on a fabric that is water soluble or that disintegrates under heat. This approach is often found in applications for tissue engineering, lightweight and reinforcement structure development.

Other advantageous characteristics of embroidery are dimensional stability of the developed structures and good reproducibility of the manufacturing process. Moreover, pattern creation with CAD software ensures rapid prototyping (40).

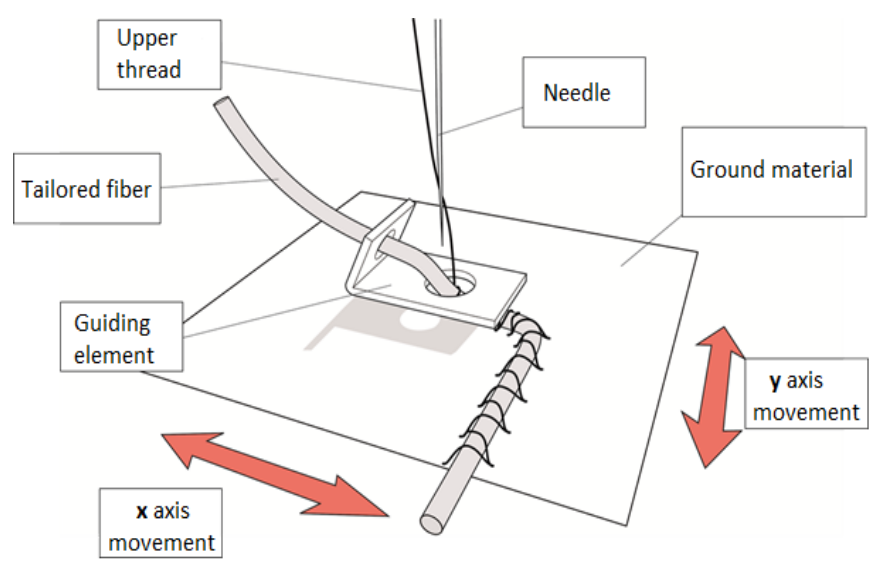

Fig. 1. The principle of the Tailored Fiber Placement (TFP) by embroidery. 

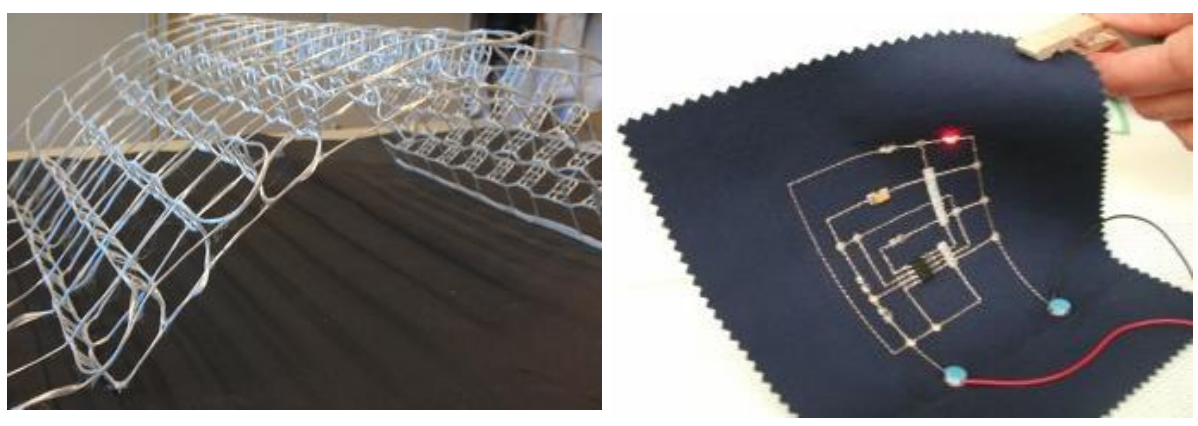

(b)

(a)

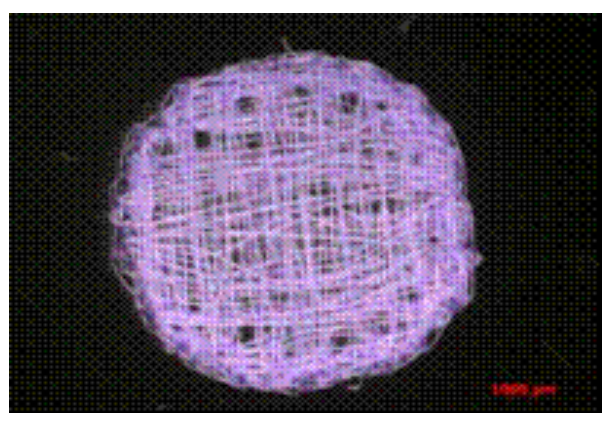

(c)

Fig. 2. Examples of technical embroidery applications: (a) 3D curved reinforcement structure (3); (b) embroidered circuit (4); (c) embroidered scaffold construction (4).

Generally, technical applications of embroidery can be classified according to three main application fields, namely, engineering, medicine and smart textiles (Table I). Fig. 2 displays representative examples of prototypes developed by embroidery technology referred to each of the mentioned application.

Embroidered reinforcement structures have applications in construction, automotive and aerospace engineering. The specific characteristic of such composite reinforcements developed by TFP technique is their anisotropic properties due to the significant influence of fiber orientation on the stresses in the components. Physical properties of the embroidered structure can be modeled using analytical and numerical calculation methods (5) - (8).

Embroidery is also applied in medical textile production and tissue engineering. In this sphere, embroidery is a relatively new technology, but it is already successfully used for wound- dressing development and the creation of three-dimensional structures from fine polymer materials for tissue engineering solutions.

Finally, embroidery is one of the most often used technologies in the sphere of smart textiles and provides a great asset in wearable and flexible electronics development. It mostly involves application of conductive materials, thus, it is often referred to as electronic embroidery or e-broidery. Conductive yarns are used for interconnection of textileintegrated electronics, development of embroidered circuits and heating grids (11). Although electronic embroidery carries functional tasks in smart textiles, it has become a key solution in fashion and interior design to manufacture textiles with integrated LEDs. Some research projects have also demonstrated opportunities to apply the embroidery technology for the development of textile antenna and coil for magnetic resonance sensors (12) - (16), (19).

TABLE I

SUMMARY OF TECHNICAL EMBROIDERY APPLICATIONS

\begin{tabular}{|c|c|c|c|c|}
\hline \multicolumn{2}{|c|}{ Application } & Function & Structural element & Technique \\
\hline \multirow{3}{*}{ Engineering } & Aerospace & Lightweight & Composite construction & $\begin{array}{c}\text { 3D and 2D embroidery by } \\
\text { TFP }\end{array}$ \\
\hline & Construction & $\begin{array}{c}\text { Lightweight structures } \\
\text { Reinforcement } \\
\text { Structural health monitoring }\end{array}$ & $\begin{array}{l}\text { Composite construction } \\
\text { Textile sensors }\end{array}$ & $\begin{array}{c}\text { 3D and 2D embroidery by } \\
\text { TFP }\end{array}$ \\
\hline & Automotive & $\begin{array}{l}\text { Lightweight structures } \\
\text { Functional integration } \\
\text { Structural health monitoring }\end{array}$ & $\begin{array}{c}\text { Composite construction } \\
\text { Textile sensors } \\
\text { Heating elements for car seats } \\
\text { Textile communication interface }\end{array}$ & $\begin{array}{c}\text { 3D and 2D embroidery by } \\
\text { TFP }\end{array}$ \\
\hline \multirow{2}{*}{ Medicine } & Wound-dressing & $\begin{array}{c}\text { Healing encouragement } \\
\text { Wound condition monitoring }\end{array}$ & $\begin{array}{c}\text { Wound-dressing material } \\
\text { Textile bio-sensor }\end{array}$ & $\begin{array}{c}\text { 3D and 2D embroidery by } \\
\text { TFP }\end{array}$ \\
\hline & Tissue Engineering & $\begin{array}{c}\text { Cell distribution } \\
\text { Cell adhesion } \\
\end{array}$ & Scaffold & $\begin{array}{l}\text { 3D embroidery by TFP } \\
\text { and chemical embroidery }\end{array}$ \\
\hline \multirow{4}{*}{$\begin{array}{c}\text { Smart } \\
\text { textiles }\end{array}$} & Bio-sensing & $\begin{array}{c}\text { Biomedical monitoring and } \\
\text { biofeedback }\end{array}$ & Textile bio-sensors & 2D embroidery by TFP \\
\hline & Physical sensing & Physical measurements & Textile sensors & 2D embroidery by TFP \\
\hline & $\begin{array}{l}\text { Therapeutic treatment } \\
\text { and wellness }\end{array}$ & $\begin{array}{l}\text { Electro-stimulation } \\
\text { Heating }\end{array}$ & Actuators & 2D embroidery by TFP \\
\hline & Cross-functional & $\begin{array}{c}\text { Communication } \\
\text { Interconnection } \\
\text { Textile interface } \\
\text { Electromagnetic induction } \\
\text { Energy supply }\end{array}$ & $\begin{array}{c}\text { Textile antenna } \\
\text { Electro-conductive tracks and } \\
\text { embroidered circuits } \\
\text { Physical sensors and actuators } \\
\text { Electromagnetic coil } \\
\text { Embroidered battery }\end{array}$ & 2D embroidery by TFP \\
\hline
\end{tabular}




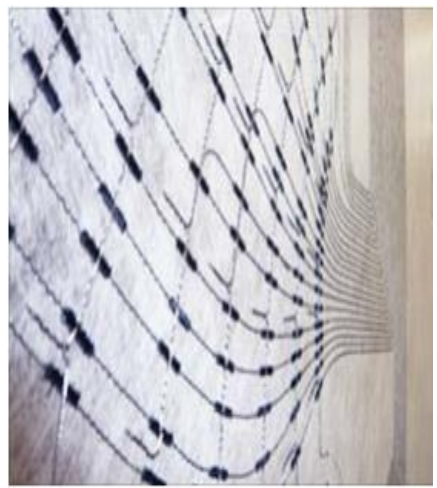

(a)

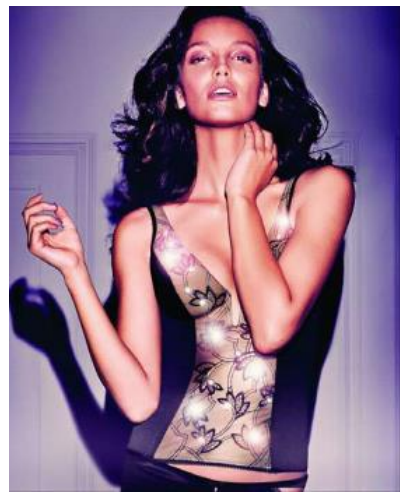

(b)

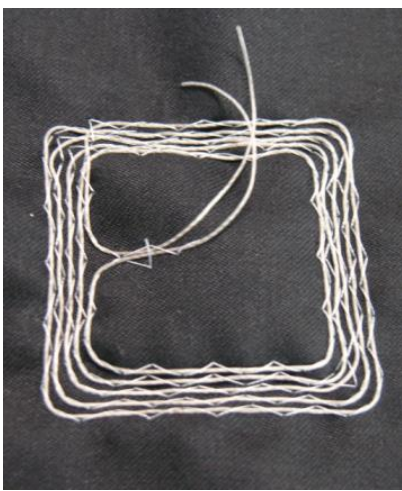

(c)

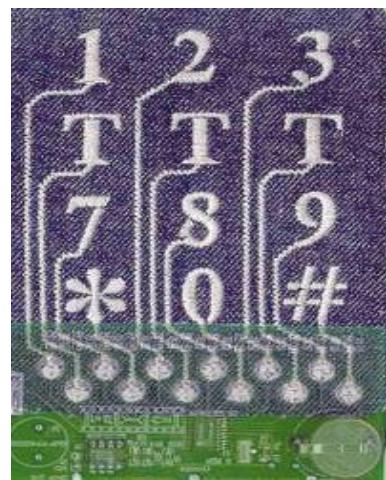

(d)

Fig. 3. Cross-functional applications of technical embroidery: (a), (b) electro-conductive interconnections for technical textiles and fashion products (Forster Rohner AG); (c) embroidered textile antenna (ITA, RWTH Aachen); (d) embroidered keypad (19).

Moreover, this combination of technologic approach and use of conductive materials ensures vast range of possibilities in textile sensor development for such biomedical and physical applications as assessment of cardiac, muscle and neural activity, pressure and strain measurements (20), (21), (23) - (25), (29) - (38). Sensing properties of textiles and compounds developed from textile materials are of great importance in protective and medical functional clothing and textiles (9). The paper provides a review of some embroidery applications in smart textiles and explores opportunities of the embroidered textile sensor design for temperature and humidity measurements.

\section{EMBROIDERY IN SMART TEXTILES}

As it has been mentioned above, smart and intelligent textiles is a vast multidisciplinary research field that brings together design, textile technologies, electrical engineering and ICT in order to develop new products matching specific aesthetic, functional and technical requirements. Technical embroidery brings solutions for implementation of new products that find applications across fashion and décor textiles, and technical ones.

\section{A. Cross-Functional Applications}

Cross-functional applications of embroidery technology can be primarily referred with ensuring textiles and clothing with such functions as communication and electronics interconnection (10), (39). Moreover, those can be associated with textile interfaces and other functional elements that do not correspond to other groups.

TFP embroidery technology is a universal technique for electro-conductive interconnection development that is highly required in implementation of intelligent products for fashion, décor, functional clothing and technical textiles (Fig. 3). The main advantage of the technique is the encouragement of vast opportunities in product technical design by positioning the electro-conductive cord across the basis material. Conductive yarns of different origin and structure, as well as conductor monofilaments are used for electronics interconnection as electro-conductive tracks according to specific technical requirements. Namely, they can carry the function of power supply and data transmission. Power supply provided by embroidered conductive textile tracks is effectively used in wearable technologies and smart textiles for a great variety of functional applications and design, especially in lightening textiles with LED technology involved. A number of spectacular examples of the technology applications in functional smart textiles are brought by the research teams of TTIV Greiz (Textilforschungsinstitut Thüringen-Vogtland e. V.) and Ghent University that have explored a variety of designs, manufacturing scenarios and characterization of flexible conductive connectors and circuit boards (4), (10) - (11), (17). On the other side, a Swiss company Forster Rohner AG offers innovative design solutions for clothing and interior textiles supported by LED and embroidery technology.

Another initial feature in the development of smart clothing is ensuring of communication or/and biofeedback with the wearer. Several research projects have explored the possibilities of developing textile antennas for smart clothing applications that can provide data transmission and become an asset in manufacturing of wearable telecommunication and biomonitoring systems (13) - (16). Electromagnetic properties of electro-conductive textile encourage investigations in developing textile-based communication systems. Such textile antennas are resistive to multiple deformations that extend its potential applications, especially in the sphere of smart clothing. Moreover, embroidery as a technological solution ensures the maintenance of textile manufacturing and processing, thereby keeping the production process efficient and simple. For example, Osman et al. demonstrate a prototype of an Ultra-Wideband (UWB) antenna fully implemented from textile materials with embroidery technology. The communication system is built using silver Plated Nylon thread on a textile substrate (100\% cotton fabric) (13). The resistance of such textile antennas to multiple mechanical deformations extends their potential applications and makes them especially promising for smart clothing. Moreover, this approach is fully based on textile manufacturing and processing technologies, thereby keeping the production efficient and simple. Another example of a fully textile antenna developed on textile by TFP technique was implemented at the Institute for Textile Technology of RWTH Aachen and is displayed in Fig. 3(c).

One more cross-functional application of embroidery in smart and intelligent textiles is the development of textile 
interfaces. Quite a lot of research projects address embroidery as an efficient technique, involve electrically conductive materials for textile interface manufacturing and offer a variety of implementation approaches (27). One of the classical examples of the textile interface implemented in clothing is a keypad of the Musical Jacket. The technology is based on a sandwich-structured capacitive sensor manufactured of electrically conductive textiles (9). Another promising application of textile interfaces for vehicle interior is described by Scheibner et al. (17).

Textile interface can be fully developed by embroidery or by joining technologies. In fact, there is a great variety of approaches that encourage implementation of actuators for the textile interface and involve piezoelectric, shape memory, thermo-chromic and other materials (18). According to specific technical requirements and applications, some of them can be potentially adapted to be fully carried out by embroidery technology.

Besides that, TFP embroidery technique encourages the development of other functional components for smart and wearable applications. Those include design and manufacturing of electro-magnetic coils for a variety of applications. For example, Morris et al. have developed an embroidered high frequency coil and explored its outlooks for use in magnetic resonance imaging (19).

\section{B. Therapeutic Treatment and Wellness}

Throughout last years there has been a growing interest for smart textile solutions for therapeutic treatment and wellness. The main advantage brought by smart textile technologies for therapeutic applications is ensuring of wireless and continuous treatment outside a hospital. Moreover, textiles are lightweight and possess a number of properties that can assist in the improvement of wearer's psycho-physiological comfort. In this paper only two types of textile actuators developed by embroidery technology are referred to this category.

One of them is textile electrodes for transcutaneous electrostimulations (TES). For instance, a research team from Switzerland has presented the research results on investigations in multi-channel TES electrode development. The developed electrodes consisted of multiple fabric layers and were integrated into a glove-like garment (Fig. 4(a)). One layer with electrodes manufactured with plasma coated metallized yarn contacted the skin. The second layer had an electrode wiring, but the structure of the multi-layer electrode was specifically

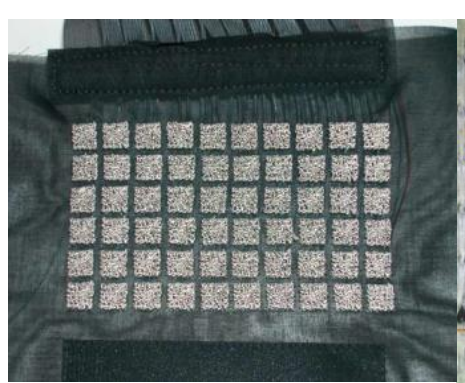

(a)

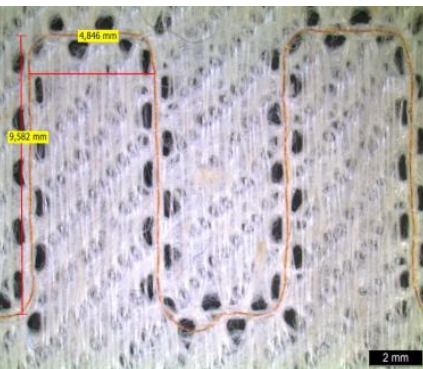

(b)
Fig. 4. (a) Transcutaneous electro-stimulation electrodes (20); (b) Prototype of an implantable electrodes for electro-stimulation [ITA, RWTH Aachen]. developed to exclude short circuit (20). Another example of structural and dimensional variations in the design of embroidered electrodes for electrical stimulation is a miniaturized meander-shape electrode developed at ITA, RWTH Aachen (Fig. 4 (b)). One segment of this electrode is approximately $9.5 \mathrm{~mm}$ x $5 \mathrm{~mm}$. Despite delicate materials used for the electrode development and fine structure, the embroidered samples can be described as reproducible and manufactured with high accuracy.

Another type of embroidered actuators is heating textiles. Those are already available on the market in a vast assortment. Generally, the idea of heating textiles is found in design of clothing, textile products for domestic use and car seats. Fig. 5 displays two examples of embroidered heating textiles.

\section{Physical Sensing}

Textile sensors that provide assessment of such universal parameters as pressure, stress, temperature and humidity already find applications in structural monitoring and healthcare. There are a number of developments manufactured by embroidery technology using conductive materials. Most of such sensors are based on estimation of physical measurements such as electrical conductivity and capacitance that can be used for the evaluation of various physical and physiological processes, and environmental phenomena. Such sensors can be implemented only by embroidery or joining the technology that incorporates different manufacturing approaches and techniques to produce separate compounds or insure a specific finishing of the development. Some examples of embroidered sensors based on the physical measurement principle are described further.

\section{Strain sensors.}

Most of the reviewed literature on embroidery applications for physical sensing focuses on strain sensor development. Primary those have technical applications and are of great importance in structural monitoring. Embroidery can provide efficient and relatively low-cost solutions that can be adjusted to specific structures and technical requirements, and ensure monitoring of stress changes inside the structure and over the object surface. The working principle of a strain sensor is usually based on estimation of resistivity variations in the embroidered compound within structure deformation. A strain sensor can be often a single conductive yarn or embroidered on a stretchable fabric as a pattern by TFP technique (22) - (23), (25). Besides applications in construction engineering, strain

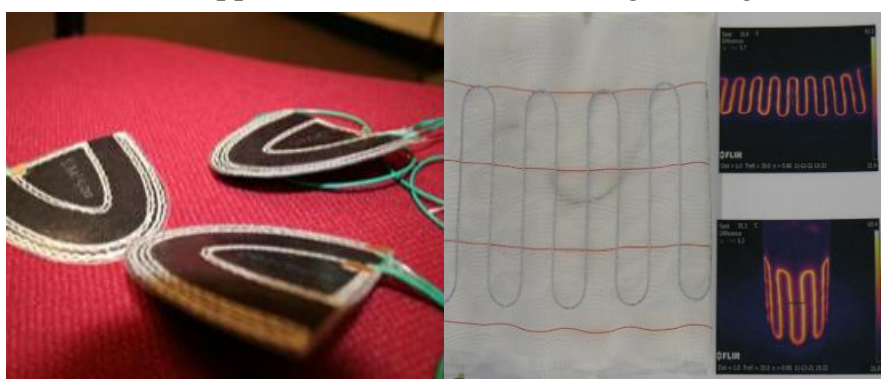

(a)

(b)

Fig. 5. Embroidered heating textile structures: (a) Forster Rohner AG; (b) heating textiles [ITA, RWTH Aachen]. 


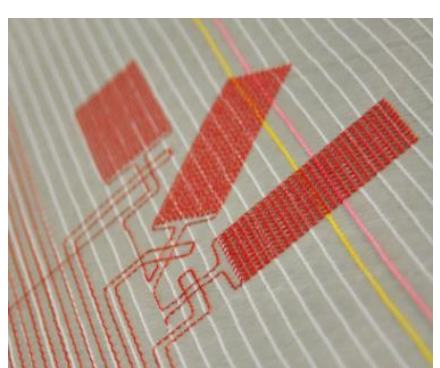

(a)

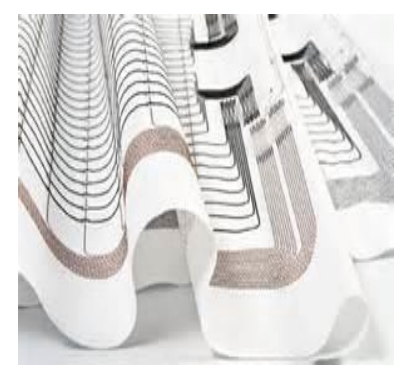

(b)
Fig. 6. Embroidered sensors based on the physical sensing: (a) stress sensor (28); (b) pressure mapping sensor (41).

textile sensors can be potentially an asset in the development of smart clothing. There are not many examples of embroidered strain sensors integrated into clothing or textiles for health monitoring, but some of the ideas can be adapted for embroidery technology. For example, strain textile gauges can find applications in dynamic respiration rate monitoring (23). Moreover, those can be also suggested as an alternative to piezoelectric and conductive elastomer sensors used for the detection and evaluation of body positioning (24), (25).

\section{Pressure sensors.}

Pressure sensors have vast applications in the field of healthcare, sports, wellness and engineering. Mostly, those are based on measurements of capacitance changes and can vary in their dimensional parameters. An advantageous characteristic of embroidered pressure sensors is the opportunity not only to measure the applied pressure, but also to monitor pressure distribution over the surface. An example of a large-scale pressure sensor implemented by embroidery technology is developed by the German company Alphafit GmbH (Fig. 6(b)) (26), (41). The textile sensor system is integrated into a mattress that provides pressure mapping of the body. The acquired measurements can be used for monitoring of body positioning and movements during sleep. Such systems can be used in such healthcare applications as estimation of the applied pressure changes in compression garments and smart textile systems for ulcer prevention. Besides pressure measurements, such sensors can be used as actuators in textile interfaces (27).

\section{Temperature sensors.}

Temperature monitoring and control is crucial in many technical, domestic and healthcare applications. In this sphere textiles also offer attractive perspectives for flexible twodimensional sensorial compound manufacturing. There are many research results published on textile temperature sensor development via fiber engineering, weaving, knitting, lithography, inkjet-printing, surface modification and joining technology. Those research projects using conductive yarns as the initial material for sensor production, mostly address the resistive working principle of temperature sensors. It is based on evaluation of resistivity changes in a metal within temperature changes and further conversion of the electrical signal to relevant values. Another approach to temperature measurements is its assessment using thermocouples. The working principle of those is based on thermoelectric effect in two metals.

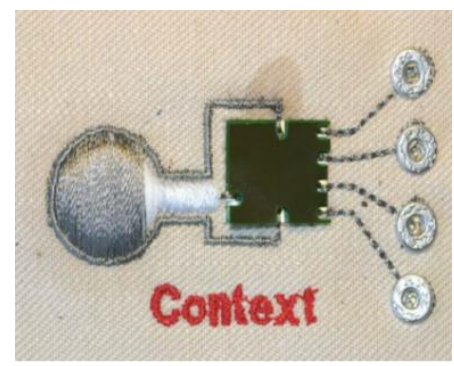

(a)

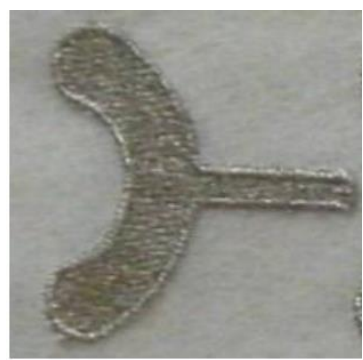

(b)
Fig. 7. Embroidered electrodes: (a) embroidered EMG electrode (35); (b) embroidered EEG electrode (39).

Both the resistive temperature sensor and the thermocouple can be implemented by embroidery. A research team from Chemnitz University has investigated embroidery applications for both types of sensor development for temperature evaluation in lightweight composite structures (28). Another example of a temperature sensor development by embroidery was implemented in the frame of the EU research project All for Rest that focused on estimation and improvement of quality of sleep. A textile thermocouple was integrated by TFP technique into a mattress to provide microclimate control during rest.

\section{Humidity sensors.}

As well as temperature, humidity is an important parameter in many processes. Humidity level control is important in such technical applications as structural health monitoring, manufacturing and operation of machines. Moreover, it is essential in a number of physiological and biological processes. A number of research projects are devoted to development opportunities of humidity textile sensors. According to the relevant literature review, very few investigations have involved embroidery for the sensor design. Most of them addressed such technologies as fiber coating, weaving and joining technology bringing together weaving and lithography, and inkjet-printing (29) - (34), (42).

\section{Bio-Sensing}

Bio-sensing properties of embroidered compounds can be referred as estimation of physiological data and assessment of biochemical processes. In smart textiles applications, textile electrodes and biochemical sensors take crucial place in the research $(43)-(50)$.

Textile electrodes.

There is a great number of research projects that have investigated opportunities and specifics of embroidered electrodes for electrocardiography, electromyography and encephalography measurements (4), (36) - (40). Such electrodes are usually developed with the use of conductive yarns and are able to register electric potential generated by muscles, electric activity of neurons of the brain, and measure electrical conductance of skin.

\section{CONCLUSION AND DISCUSSION}

In this study, general applications of technical embroidery for intelligent and smart textiles are reviewed. Summarizing the discussed information, those can be referred to three general 
application groups: engineering, medicine and smart textiles. The key applications of embroidery in engineering are structure reinforcement and lightweight constructions. In medical applications, embroidery is found as one of the key technologies for implant development and is often combined with other approaches such as electrospinning in order to obtain a structure with the most appropriate properties. Nevertheless, the study is focusing on smart textiles that is a relatively new, but rapidly developing and expanding sphere.

In general, TFP technique and standard embroidery are two embroidery approaches mostly used to develop interactive textile structures. One of the most demanded additional values that can be provided by smart textiles products is sensing and monitoring of physical, chemical and bio-chemical parameters. Textile sensors are often outstanding candidates to be integrated into clothing, other textiles and flexible structures. Although numerous research projects describe a great variety of scenarios for textile sensor implementation and technological approaches, embroidery is remaining one of the advantageous technologies due to the opportunity to vary in sensor geometry design and material choice.

In this paper, applications of technical embroidery with TFP and double lock-stitch techniques were divided into several categories according to the reviewed literature on smart textiles. Although embroidery encourages efficient development of textile interfaces, cabling, contacting joints, antennas and other structures, one of the most addressed applications is the development of textile sensors for physical and bio-chemical sensing. Architecture and operation principle of textile sensors is usually transferred from the conventional ones. Regarding particularities of sensor application, such sensors can be implemented with a variety of materials such as electrically conductive yarns, piezoresistive and optical fibers.

The main types of sensors that can be implemented by embroidery are described in the examples of developments. The state-of-the-art reveals the potential for embroidery applications for efficient development of intelligent innovative products. Nevertheless, most of them still originate in $R \& D$ sphere, but the number of such products based on embroidery technology is constantly increasing on the market. For this reason, it can be concluded that embroidery is not only beneficial for the applied research, but has also a number of advantages to drive technology transfer to industry due to efficient and continuous production.

\section{REFERENCES}

1. Selm, B., Bischoff, B., Seidl, R. Embroidery and Smart Textiles. In: Smart Fibers, Fabrics and Clothing. Cambridge: Woodhead Publishing, 2001, pp. 218-225. http://doi.org/d3xx6z

2. Report on TFP Technique (Erläuterungen zur TFP-Technologie) [online]. [viewed 20.11.2014]. Available from: http://www.hightexdresden.de/downloads/Hightex.pdf

3. Image. [online] [viewed 17.10.2013]. Available from: http://www.uibk.ac.at/textilchemie/texchem/texon-.html

4. Hanus, S. et al. Smart Textiles for Medical Applications [online]. Smar Textiles in Thueringen/Germany, Textile Research Institute ThuringiaVogtland e.V. 2012. [viewed 28.09.2013]. Available from: d.zschenderlein@ttiv-greiz.de

5. Tong, L., Mouritz, A.P., Bannister, M.K. 3D Fiber Reinforced Polymer Composites. Elsevier; 2002, pp. 45-46.
6. Aschenbrenner, L., Temmen, H., Degenhardt, R. Tailored Fiber Placement Technology-Optimisation and Computation of CFRP Structures [online]. DLR, Institute of Composite Structures and Adaptive Systems. [viewed 21.10.2013]. Available from: www.elib.dlr.de/.../1/10-ESACOMP_24_04 07_TFP.pdf

7. Mesejo-Chiong, A., Leon-Mecias, A., Shiebel, P.H. Modelling Deformable Filament Bundles by Means of Mass-Spring Systems for the design of carbon Reinforced Materials. Articulated Motion and Deformable Objects. In: 7th International Conference. AMDO 2012, pp. 219-229.

8. Post, E.R., Orth, M., Russo, P.R., Gershenfeld, N. E-Broidery: Design and Fabrication of Textile-Based Computing. IBM System Journal. 2000, 39, pp. 840-860. http://doi.org/dvqhns

9. Gupta, D. Funtional Clothing-Definition and Classification. Indian Journal and Fibre and Textile research. 2011, 36, pp. 321-326.

10. Linz, T. Analysis of Failure Mechanisms of Machine Embroidered Electrical Contacts and Solutions for Improved Reliability. PhD Thesis, Ghent University, 2012.

11. Linz, T., Vieroth, R., Dils, C. Embroidered Interconnections and Encapsulation for Electronics in Textiles for Wearable Electronics Applications. Advances in Science and Technology. 2008, 60, pp. 85-94. http://doi.org/csj9z7

12. Osman, M. A. R., Rahim, M. K. A., Samsuti, N.A. et al. Embroidered Fully Textile Wearable Antenna for Medical Monitoring Applications. Progress in Electromagnetics Research. 2011, 177, pp. 321-337. http://doi.org/22h

13. Liu, U., Lu, Y., Qui, S., Li, P. Electromagnetic properties of ElectroTextiles for Wearable Antennas Applications. Frontiers of Electrical and Electronic Engineering in China. 2011, vol. 6, Issue 4, pp. 563-566. http://doi.org/c78mdr

14. Kaufmann, T. Comparison of Fabric and Embroidered Dipole Antennas. In: $7^{\text {th }}$ European Conference on Antennas and Propagation (EuCAP), 2013, pp. 3252-3255.

15. Rogier, H., Declercq, F., Van Torre, T., Valozzi, L. Active Textile Antennas as a Platform for More Energy-Efficient and Reliable Wireless Links in Healthcare. In: Wireless Mobile Communication and Healthcare, 2012, pp. 318-325.

16. Sankaralingam, S., Dhar, S., Gupta, B. Performance of Electro-Textile Wearable Circular Patch Antennas in the Vicinity of Human Body at 2.45 GHz. Procedia Engineering. 2013, vol. 64, pp. 179-184. http://doi.org/22j

17. Scheibner, W., Ullrich, K., Neudeck, A., Moehring, U. Textile Sensors for the Vehicle Interior, Textilforschungsinstitut Thüringen-Vogtland e. V. (TTIV) Greiz, 2011. [online]. [viewed 15.07.2013]. Available from: www.ama-science.org/home/getFile/AGH5,

18. Dakova, S., Dumont, R. An Overview of Textile Interfaces [online]. [viewed 25.20.2013]. Available from: http://hci.rwth-aachen.de/tikidownload wiki_attachment.php?attId=1176

19. Morris, R.H., McHale, G., Dias, T., Newton, M.I. Embroidered Coils for Magnetic Resonance Sensors. Electronics. 2013, vol. 2, pp. 168-177. http://doi.org/22k

20. Keller, K., Kuhn, A. Electrodes for Transcutaneous (Surface) Electrical Stimulation. Journal of Automatic Control. University of Belgrad, 2008, vol. 18 , pp. 35-45. http://doi.org/b68g93

21. Data Sheet: Integrated Embroidered Sensor [online]. [viewed 17.11.2013]. Available from: http://www.fibercheck.de/technologie.html

22. Vena, A., Koski, K., Morafi, E. et al. An Embroidered Two-Dimensional Chipless Strain Sensor for Wireless Structural Deformation Monitoring. IEEE Sensors Journal. 2013, vol. 13, pp. 4627-4637. http://doi.org/22m

23. Teofilo, L, Lee-Chiong, Jr. Monitoring Respiration during Sleep. Clinics in Chest Medicine. 2003, vol. 24, pp. 297-306. http://doi.org/dtt5bm

24. Mokhlespour, M.I, Zobeiri, O., Narimani, R. Design and Prototyping of Wearable Measuring System for Trunk Movement Using Textile Sensors. In: $20^{\text {th }}$ Iranian Conference on Electrical Engineering. 2012, Iran, pp. 1571-1576 http://doi.org/22n

25. Giorgino, T., Tormene, P, Lorussi, F. et al. Sensor Evaluation for Wearable Strain Gauges in Neurological Rehabilitation. Transactions on Neural Systems and Rehabilitation Engineering. 2009, vol. 17, pp. 409-415. http://doi.org/bzr32p

26. Product information. Alphamat [online]. [viewed 28.11.2014]. Available from: http://www.alpha-fit.de/produkte/alphamat.html

27. Weinberg, G., Orth, M., Russo, P. The Embroidered Musical Ball: A Squeezable Instrument for Expressive Performance. In: CHI 2000. Extended Abstracts on Human Factors in Computing Systems. 2000, New York, pp. 283-284. 
28. Elsner, H. Textile Technological Intergration of Sensor Modules in Lightweight Composite Structures and Possible Applications. In: Activities in Adaptronics [online]. [viewed 12.10.2012]. Available from: www.lse-chemnitz.de

29. Pereira, T., Silva, P., Carvalho, H., Carvalho, M., Textile Moisture Sensor Matrix for Monitoring of Disabled and Bed-Rest Patients. IEEE International Conference on Computure as a Tool (Eruocon). 2011, pp. 1-4.

30. Devaux, E., Aubry, C., Campagne, C., Rochery, M., PLA/Carbon Nanotubes Multifilament Yarns for Relative Humidity Textile Sensor. Journal of Engineered Fibers and Fabrics. 2011, vol. 6, Issue 3, pp. 13-24.

31. Kindeldei, T., Mattana, G., Leuenberger, D. et al., Feasability of Printing Woven Humidity and Temperature Sensors for Integration into Electronic Textiles. Advances in Science and Technology. 2013, vol. 80, pp. 77-82. http://doi.org/22q

32. Kindeldei, T., Zysset, C., Cherenack, K.H., Troester, G., A Textile Integrated Sensor System for Monitoring Humidity and Temperature. In: Proc. Transducers. 2011, pp. 1156-1159.

33. Rumpf, S., Patient Monitoring System Based on Textile Sensor Technology. Innovations Forum Heidelberg 2008 [online]. [viewed 27.10.12] Available from: http://www.heidelberger-innovationsforum.de/fileadmin/ heidelberger/downloads/Praesentationen_April08/15_Rumpf.pdf

34. Swaminathan, A., Khan, M. B., Electrical Characterization of Textile Sensor for Moisture detection. Master Thesis. School of Engineering of University of Boras, 2011

35. Linz, T., Gourmelon, L., Langereis, G. Contactless EMG Sensors Embroidered onto Textile. In: 4th International Workshop on Wearable and Implantable Body Sensor Networks (BSN 2007) Proceeding. 2007, vol. 13, pp. 29-34.

36. Peltokangas, M., Verhno, J., Vehkaoja, A. Night-Time EKG and HRV Monitoring with Bed Sheet Integrated Textile Electrodes. In: IEEE Transations on Information Technology in Biomedicine. 2012, vol. 16, pp. 935-943.

37. Pola, T., Vanhala, J. Textile Electrodes in ECG Measurement. In: $3 d$ Interantional Conference on Intelligent Sensors, Sensor Networks and information. Melbourne, 2007, pp. 635-639.

38. Kannaian, T., Neelaveni, R., Thilagavathi, G. Design and development of Embroidered Textile Electrodes for Continuous Measurewment of Electrocardiogramm Signals. Journal od Industrial Textiles. 2012, pp. $1-16$.

39. Kasurina, I., Valisevskis, A., Ziemele, I., Briedis, U., Vilumsone, A. Improvements of Smart Garment Electronic Contaact System. Advances in Science and Technology. 2013, vol. 80, pp. 90-95.

40. Radavičiene, S., Juciene, M., Juchnevičiene, Ž., Čepukone, L., Viḷumsone, A., Briedis, U., Baltina, I. Analysis of Shape Nonconformity between Embroidered Element. Materials Science. Medžiagotyra, 2014, vol. 20 , no. 1 , pp. $84-89$.

41. Image: Alphmat pressure mapping sensor [online]. [viewed 28.11.2014] Available from: http://www.nova-nex.com/de/projekte/alphamat-smart-sock

42. Parkova, I., Vališevskis, A., Briedis, U., Vilumsone, A. Design of Textile Moisture Sensor for Enuresis Alarm System. Material science. Textile and clothing technology. no. 7, 2012, pp. 44-49. ISSN 1691-3132.

43. Pasche, S.Schyrr, Wenger, B. et al. Smart Textiles with Biosensing Capabilities. Advances in Science and Technologies. Vol.80, 2013, pp. $129-135$.

44. Nocke, A. et. al. Minituarized Textile-Based Multi-Layer $\mathrm{pH}$ sensor for Wound Monitoring Applications. Autex Research Journal. vol. 12, Issue 1, 2012, pp. 20-22. http://doi.org/22r

45. Wong, W.C.et al. Miniature pH Optical Fibre Sensor based on WaistEnlarged Bitaper and Mode Excitation. Sensors and Actuators B 191. 2014, pp. 579-585. http://doi.org/22s

46. Scherer et al. Textile-based optical sensors. EMPA, Dübendorf, Smart Textile. 30.09.2011.

47. Sharp, D., Davis, J. Integrated urate sensors for detecting wound infection. Electrochemistry Communications. vol. 10, 2008, pp. 709-713. http://doi.org/ft $95 \mathrm{~b} 7$

48. Sharp, D., Forsythe, S., Davis, J. Carbon fibre composites: integrated electrochemical sensors for wound management. Journal of Biochemistry. vol. 144, 2008 , pp. 87-93.

49. Connolly, P.; McColl, D. (18.04.2005): Wound Dressings and Performance Measurement of Such Dressings. US020080171957A1.

50. Guinovart, T. et al. Bandage-Based Wearable Potentiometric Sensor for Monitoring Wound pH. Electroanalysis. vol. 26, 2014, pp. 1345-1354. http://doi.org/f2qk9x

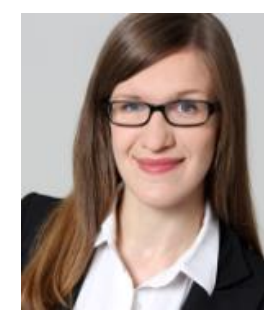

Viktorija Mecnika holds the Ms. sc. ing. degree. Since February 2014, she has been an Assistant Researcher with Institut fuer Textiltechnik (ITA) of RWTH Aachen University. In 2010, she received the Master degree in Clothing Technology from the Institute of Textile Technology and Design of Riga Technical University. She is presently studying towards the Doctoral degree. During her Master studies she gained work experience in textiles and apparel retail and fashion management with the focus on high-street and luxury brands. In 2010, she was Assistant Researcher at Riga Technical University and University of Latvia ("Biophotonics Research Group"). From 2012 to 2013, she was involved in research activities as a guest researcher at Institut fue Textiltechnik - RWTH Aachen, Germany. Her research field is innovative textiles and clothing for technical and functional applications.

Address: Institut fuer Textiltechnik of RWTH Aachen University, OttoBlumenthalstr. 1, 52074 Aachen, Germany.

E-mail: viktorija.mecnika@ita.rwth-aachen.de

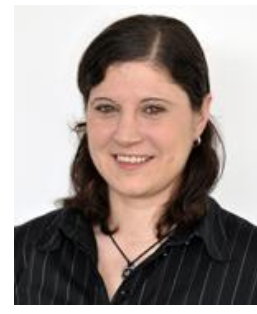

Melanie Hoerr holds the Dipl-Ing. degree and is a Doctoral student withat Institut fuer Textiltechnik of RWTH Aachen University, Germany. She received her diploma degree in Mechanical Engineering from RWTH Aachen University in 2010 after finishing her training as industrial mechanic (specialty operating technology).

Since 2011, she has been an Assistant Researcher in the field of Medical Textiles with the Institut fuer Textiltechnik, RWTH Aachen University. She is Head of the research group "Medical Smart Textiles".

Her main research interests include textile sensors and actuators for medical applications, as well as embroidery technology with a focus on embroidered electrodes for the monitoring of bodily functions.

Address: Institut fuer Textiltechnik of RWTH Aachen University, OttoBlumenthalstr. 1, 52074 Aachen, Germany.

E-mail: melanie.hoerr@ita.rwth-aachen.de

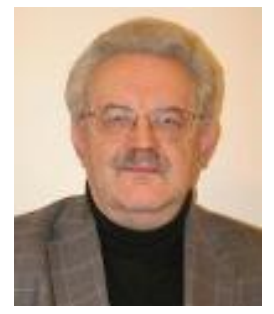

Ivars Krievins received the $D r$. sc. ing. degree after professional studies at the Leningrad Technological Institute for Textile and "Light" Industry (1969 - 1974). $\mathrm{He}$ is a Designer and Technologist of Sewn Products Engineering.

$\mathrm{He}$ is currently an Associate Professor with the Institute of Design Technologies and the Department of Clothing and Textile Technologies of Riga Technical University (RTU). Since 1992, he has been the Chairman of the Textile Terminology Commission of the Latvian Academy of Sciences; From 1997 to 2002, he was the Chairman of the Technical Committee for National Standardization Body LVS/STK/41 "Textiles and Leather"; Since 2000, he has been a Textile Expert of the Ministry of Economics for the EU Textile Labeling Committee; From 1993 to 2000, he was a member of The International Textile Institute; From 1998 to 2005, he was a member of the RTU Promotion Council RTU-P-11.

Address: Institute of Design Technologies, Riga Technical University, Azenes Str. 18, Riga, LV-1048, Latvia. E-mail: ivars.krievins@ rtu.lv

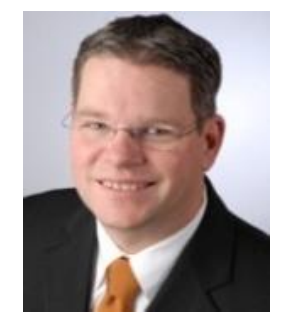

Stefan Jockenhoevel holds the Univ.-Prof. Dr. med. degree. He is a Professor with the Helmholtz Institute Aachen and the Institut fuer Textiltechnik of RWTH Aachen University, Germany. In 1995, he graduated in Medicine from RWTH Aachen University and started his clinical practice in Thoracic \& Cardiovascular Surgery at the Heart Centre Baden, followed by positions at the University Hospital Aachen, the University Hospital in Zurich, and later as a senior physician at the Institute National de Chirurgie

Cardiaque, Luxembourg. Since 2011, he is holding the transfaculty professorship for Tissue Engineering \& Textile Implants, heading the Division of Tissue Engineering \& Biomaterials at the Helmholtz Institute Aachen (Medical Faculty) and the Division of Life Science \& Smart Textiles at the Institut fuer Textiltechnik (Faculty of Mechanical Engineering) of RWTH Aachen University.

Address: Institut fuer Textiltechnik of RWTH Aachen University, OttoBlumenthalstr. 1, 52074 Aachen, Germany.

E-mail: stefan.jockenhoevel@ita.rwth-aachen.de 


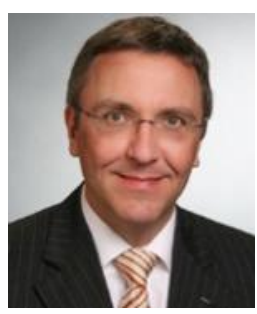

Thomas Gries, Univ.-Prof. Prof. h.c. Dr.-Ing. Dipl.Wirt. Ing., studied Mechanical Engineering at RWTH Aachen University. In 1992, he received the degree in Economic Engineering studies in parallel to his $\mathrm{PhD}$ studies. After receiving the Dr.-Ing. degree in Mechanical Engineering in 1995, he worked at the Department of Technologies for Fibers at Lurgi Zimmer AG at an international level. Since 2001, Professor Gries is the director of the Institut fuer Textiltechnik of RWTH Aachen University.

He coordinates and consults multi-disciplinary research activities and projects. Additionally to his research and administrative activities at the Institute of Textile Technology - RWTH Aachen University, he takes a number of honorary positions and superior duties such as being a spokesman and chairman at scientific forums, events and communities. In March 2013, he was granted an Honorary Professorship at the Lomonosov Moscow State University.

Address: Institut fuer Textiltechnik of RWTH Aachen University, OttoBlumenthalstr. 1, 52074 Aachen, Germany.

E-mail: thomas.gries@ita.rwth-aachen.de

Viktorija Mečñika, Melanie Hoerr, Ivars Krieviṇš, Stephan Jockenhoevel, Thomas Gries. Automatizētās ižš̄šanas pielietojumi viedo tekstiliju izstrādei Izšǔšana ir tradicionāli pazīstama kā tekstiliju dekorěšanas paṇēmiens. Kopš pēejējās desmitgadēs līdz ar strauju attīstîbu tehnisko tekstiliju nišă un š̄is sfēras nozīmīguma pieaugumu apgéēbu un tekstiltehnolog̣iju, kā arī saistīto disciplīnu inovāciju un pētniecības jomās, modernās automatizētās izšǔšanas tehnolog̣ijas ir plaši pielietojamas tehnisko tekstiliju funkcionālā apstrādē un ražošanā. Interese par izšǔšanas tehnologijām šajā sfērā lielākoties ir saistîta ar tehnolog̣iskām iespējām veidot trīsdimensionālās atvieglotās konstrukcijas un izvietot pavedienus visos virzienos uz materiāla virsmas, veidojot formas ar sarežǵītu ǵeometriju. Tehnisko tekstiliju joma ietver arī tādus relatīvi jaunus materiālus kā viedās un elektroniskās tekstilijas, kuru automatizētai izšǔšanai ir liela pielietošanas nozīme. Dažādas izšǔšanas metodes ir pielietojamas viedo tekstiliju izstrādei mediciniskiem, inženierzinātṇu, būves un citiem nolūkiem. Piemēram, veselības aprūpes un medicīnas jomā automatizētā izšǔšana ir veiksmīgi pielietojama jauno brūču pārsēju un tekstila implantu izstrādē. Ar izšǔšanas panēmienu ir plašas iespējas izstrādāt tādus funkcionālus elementus kā tekstila sensorus, tekstila sildelementus, komunikāciju pieslēgvietas (interfeisus) vai komunikācijas panel̦us un elektrovadošas infrastruktūras visiem minētajiem pielietojumiem. Neskatoties uz to, ka arī citas tekstila tehnologijas ir plaši pielietojamas viedo tekstiliju jomā, automatizētā izšūšana sniedz tādas priekšrocības kā lielā dažādība apstrādes materiālos no loti smalkiem polimēru tekstila pavedieniem līdz daudz filamentu oglekḷa šķiedru pavedieniem un metāla stieplēm, izveidoto konstrukciju stabilitāte, laika taupīgs prototipa dizaina un veidošanas process utt.

Kaut gan viedās tekstilijas piedāvā lielu tehnisko iespēju klāstu dažādiem pielietojumiem, viena no perspektīvākajām nišām ir veselības aprūpes un medicīnas joma. Līdz ar to šajā rakstā lielākā uzmanība tiek pievērsta tieši šiem pielietojumiem. Rakstā ir apkopota informācija par vairākiem tekstila sensora veidiem. Īpaša izmanība ir pievērsta TFP (anglu val. Tailored Fibre Placement) izšǔšanas metodei.

Виктория Мечника, Мелани Хёрр, Иварс Криевиньш, Стефан Йокенхёфель, Томас Грис. Применения технической вышивки в области высокотехничного текстиля.

Вышивка традиционно известна как техника декоративной отделки текстиля. Тем не менее, в последние десятилетия вместе со стремительным развитием рынка технического текстиля и роста его значимости в сфере лёгкой промышленности, а также в области кросс-дисциплинарных научноисследовательских разработок, современная автоматизированная вышивка получает всё больше именно технических применений. Рост интереса к автоматизированной вышивке в основном связан с такими технологическими возможностями, как разработка облегчённых конструкций, создание трёхмерных структур из текстильных композитных материалов, а также размещение обрабатоваемого волокна во всех направлениях для проектирования функциональных элементов со сложной геометрией. Отрасль технического текстиля включает в себя также такую такие относительно новые виды, как высокотехнологичиный текстиль и так называемый «электронный» текстиль, где автоматизированная вышивка находит широкое применение. Различные методы вышивки применяются в разработках высокотехнологичного текстиля для таких отраслей, как медицина, строительное и инженерное дело. Например, в медицинской сфере автоматизированная вышивка успешно применяется для разработки текстильных имплантантов и медицинских повязок нового поколения. С помошью технической вышивки возможна также разработка таких функциональных элементов, как текстильные датчики, нагревающие элементы, инфракстуры электропроводящих элементов, а также интерфейсов или панелей для коммуникации, например, клавиатуры или кнопки для активирования и регуляции интегрированних в текстиль приборов для всех вышеупомянутых применений. Несмотря на то, что в разработке высокотехнологичного текстиля ширико применяются и другие текстильные технологии, техническая вышивка имеет ряд преимуществ, таких, как большое разнообразие материалов, которые могут использованы в разработках, начиная от тонких полимерных монофиламентов до металических проволок и мультифиламентарного углеводородного волокна. Более того, созданные с помошью технической вышивки конструкции и элементы отличаются стабильностью конструкции, а также эффективностью процесса разработки дизайна и проектирования прототипа. Несмотря на то, что в области высокотехнологичного текстиля имеется множество возможностей по его применению, одним из наиболее перспективных направлений можно считать разработки в области медицины, здравоохранения и ухода. Принимая во внимания эти тенденции, в рамках данного аналитического обзора основное внимание авторов обращено к использованию автоматизированной машинной вышивки именно для медицинских целей и её применений для улучшения системы и приспособлений по уходу за пациентами, например, текстильные изделия, оснащенные датчиками. В статье обобщена информация о различних видах существующих на данное время текстильных датчиков. Наибольшее вниманние в работе отведено методу технической вышивки, называемой ТФП (англ.-Tailored Fibre Placement). 